\title{
BIAXIAL RESPONSE OF RUBBER AND RAT RIGHT-VENTRICLE TISSUE
}

\author{
João Vitor da Silva Moreira ${ }^{1}$ \\ Daniela Valdez-Jasso²
}

Resumo: The objective of this study is to evaluate the differences in deformation presented by a latex material and a Rat Right-Ventricle tissue under biaxial loading. In order to perform the testing, it was used a planar biaxial loading technique, and the collected data was used to measure the stretching response of each material. The samples were stretched in both directions ( $x$ and $y$ axis) at the same time, until the reference markers placed on the materials reached a deformation of $10 \%$ of its original distance from the initial position. Isoparametric mapping was used to analyze the markers displacement, and according to the results, it was possible to map the deformation response of both types of material, and correlate that to its mechanical properties.

Palavras-chave: Biomechanics; Biaxial loading; Right-Ventricle;

\footnotetext{
${ }^{1}$ Instituto De Pesquisa \& Desenvolvimento/UNIVAP, Brasil. E-mail: joaovvitor@outlook.com.

2 Instituto De Pesquisa \& Desenvolvimento/UNIVAP, Brasil. E-mail: dvj@uic.edu.
} 